\title{
FINANCIAL KNOWLEDGE, FINANCIAL WELLBEING, AND ONLINE SHOPPING ADDICTION AMONG YOUNG INDONESIANS
}

\author{
Sherly Rosalina Tanoto ${ }^{1 *}$, Evelyn $^{2}$ \\ ${ }^{1,2}$ Petra Christian University, Jl. Siwalankerto 121-131, Surabaya 60236, Indonesia \\ * Corressponding author, email: sherlytanoto@petra.ac.id
}

\begin{abstract}
With the recent booming of e-commerce business in Indonesia, it is essential to conduct further studies on online shopping addiction of Indonesians. This study aims to examine the association and effect of financial knowledge and financial wellbeing on online shopping addiction. Data was collected through an online survey of 230 young Indonesians. To analyze the data, Pearson correlation and multiple regression techniques were implemented. Outcomes of this study revealed that most respondents had medium and high levels of financial knowledge and financial wellbeing. Interestingly, addictive respondents showed high financial knowledge and financial wellbeing. Financial knowledge and financial wellbeing were positively related to online shopping addiction. The results of this study provide insights for future studies and ecommerce owners.
\end{abstract}

Keywords: Online shopping addiction, financial knowledge, financial wellbeing.

\section{Introduction}

Indonesia's economy ended on a positive outcome in 2017. Since then, it has shown healthy improvement. Indeed, according to Boediono (2018), Indonesia's real Gross Domestic Product (GDP) growth increased to 5.2 percent year over year. This result has been followed by higher poverty reduction. Analysts remarked that these outcomes were Indonesia's best performance since 2016 (Focus Economics, 2017). Moreover, it was proposed that Indonesia would be the world's $7^{\text {th }}$-largest economy, conquering Germany and the United Kingdom (Oberman, Dobbs, Budiman, Thompson, \& Rossé, 2012).

Indonesia's economic improvements, accompanied by the increase of living standards, encourage Indonesians to be more consumptive. The World Bank has stated that the strengthening of household consumption is a major cause of Indonesia's economic growth (Boediono, 2018). This data is supported by the Marginal Propensity to Consume (MPC) of Indonesian society, which tends to increase (Sari, 2014). The McKinsey Global Institute even estimated that there would be 90 million Indonesians with consumptive behavior by 2030 (Oberman et al., 2012).

The advancement in Internet technology may also affect individuals' level of consumption as the internet offers customers with a convenient way to shop products and services. Surveys conducted by Google Indonesia and Growth from Knowledge (GfK) showed that the average Indonesian community spent 4-6 hours shopping online (Barlian, 2017). Furthermore, Agus Martowardojo, the current Gove- rnor of Bank Indonesia, claimed that the total amount of money spent by Indonesian online customers reached 75 trillion Rupiah in 2017 (Oktara, 2017). It can be said that online shopping has become a new lifestyle.

Bighiu, Manolică, and Roman (2015) argued that the current spending behavior is no longer just an activity done to meet the needs. In Indonesia, middleclass societies experience a transitional pattern of consumption, from the original way to meet the basic need of fulfilling the needs of symbols, status, and lifestyle (Jati, 2015). Often people shop without planning, and for no underlying rationale, or known as compulsive buying.

There has been academic debate regarding the nature of compulsive buying whether it is an impulsecontrol, obsessive-compulsive or addictive condition (Aboujaoude, 2014). Several scholars contended that it is better to be recognized as shopping addiction because people with this behavior experienced craving, withdrawal, and loss of control (Andreassen et al., 2015; Workman \& Paper, 2010). Hence, this study adopts problematic shopping behavior as an addiction since it shows some behavioral addictions as mentioned earlier. In the context of online shopping, it is usually called online shopping addiction or Problematic Internet Shopping (PIS) (Lam \& Lam, 2017; Andreassen et al., 2015).

Lam and Lam (2017) suggested that ease of online shopping might increase the risk of online shopping addiction. However, with the growing number of online shopping service users today, online shopping addiction is becoming an acceptable and 
understandable addiction by the community (Lam \& Lam, 2017). For example, college students in Paris choose to shop online over offline due to attractive offers and an instant positive sensation (Duroy, Gorse, \& Lejoyeux, 2014). Previous studies had been investigating potential antecedents of online shopping addiction, such as personal characteristics (Rose \& Dhandayudham, 2014), cognitive appraisal (Brand, Young, Laier, Wölfling, \& Potenza, 2016; Duroy et al., 2014), and the coping style (Lo \& Harvey, 2012; Clark \& Calleja, 2008). These studies focus more on the psychological causes.

Spinella, Lester, and Yang (2014) demonstrated that online shopping addiction was related to individuals' financial behavior. Recent research showed that online shopping addiction was affected by financial literacy. Individuals with high financial literacy tend to have low online shopping addiction (Lam \& Lam 2017). Moreover, individuals with high financial worries will be more likely to be addicted to shop (Garðarsdóttir \& Dittmar, 2012). However, there is only little research on the importance of individuals' financial condition towards online shopping addiction (Lam \& Lam, 2017). Therefore, this present study aims to answer this particular question.

Given the economic situation and the recent booming of e-commerce, Indonesia will be a fascinating population to study in relation with its online shopping behavior. We contend that the rapid growth of economy and e-commerce in Indonesia promotes consumptive behavior that eventually will affect their online shopping addiction, their financial knowledge, and their financial wellbeing. Specifically, our aims are: (1) to characterize levels of financial knowledge, financial wellbeing, and online shopping addiction among young Indonesians; (2) to analyze whether differrent levels of financial knowledge and financial wellbeing will result in different levels of online shopping addiction; (3) to examine the relationship and influence of financial knowledge and financial wellbeing on online shopping addiction.

To achieve the research goals, we use cross tabulation, Pearson correlation, and multiple regression methods. The findings of this study show that most of the respondents have medium and high levels of financial knowledge and financial wellbeing. Also, less than $10 \%$ respondents are online shopping addicts and these respondents have better financial knowledge and financial conditions. Furthermore, financial knowledge and financial wellbeing are positively related to online shopping addiction. Finally, financial wellbeing significantly influences online shopping addiction.

\section{Financial Knowledge}

Financial knowledge can be defined as all essential knowledge on financial concepts, products, and services that help to make right financial decisions, such as inflation, interest, and risk (Australian Unity, 2014; Huston, 2010). This definition is in line with Bowen's (2002) statement that financial knowledge is the comprehension of main financial notions needed in individuals' daily life. Financial knowledge is obtained through an individual's education and/or experience (Huston, 2010). The concept of financial knowledge has been used with both financial literacy and financial education (Kimiyaghalam \& Safari, 2015).

According to Huston's (2010) literature review, out of 70 studies evaluated, almost $50 \%$ of them utilized the terms of financial literacy and financial knowledge interchangeably. Moreover, only $15 \%$ argued that financial literacy and financial knowledge are two distinct concepts; and, they further stated that financial knowledge is a part of financial literacy yet not parallel to financial literacy. Most definitions of financial literacy emphasize abilities and skills while financial knowledge is more about understanding of financial concepts, products, and services (Australian Unity, 2014; United States Government Accountability Office, 2012; Organization for Economic Cooperation and Development, 2012).

Within financial literacy, individuals not only have financial knowledge but they are able to make informed judgments based on their financial knowledge (Australian Unity, 2014; Huston, 2010). Hence, to measure financial literacy is more complex than financial knowledge as it needs to assess whether an individual has the ability to apply his/her financial knowledge properly. Both financial literacy and financial knowledge are human capitals with diverse constructs whereas financial education is a tool aimed at improving individuals' human capitals, namely financial literacy and financial knowledge.

\section{Financial Wellbeing}

Financial wellbeing is related to individuals' attitudes, behavior, and feelings toward their current financial situation (Australian Unity, 2014). This definition reflects subjective and personal nature as it is only the individual that can measure his/her financial wellbeing despite his/her objective financial situation (Brüggen, Hogreve, Holmlund, Kabadayi, \& Löfgren, 2017). As an illustration, individuals can be in the same income rate but have different levels of 
financial wellbeing because of their personal characteristics and values. Additionally, due to its subjective nature, an individual's social reference group may affect his/her financial wellbeing (Dolan, Peasgood, $\&$ White, 2008). In other words, what the social reference group has in relation to the individual impacts his/her financial wellbeing. These qualities of financial wellbeing are not fully captured with the traditional financial wellbeing indicators, namely income or net worth.

Financial wellbeing has been discussed in various disciplines, such as financial planning, consumer decision-making, and psychology. Due to this, there has been no agreement in the definition of financial wellbeing. In fact, past studies on financial wellbeing implemented different measurements yet they did not clarify the definition of financial wellbeing (Strömbäck, Lind, Skagerlund, Västfjäll, \& Tinghög, 2017; Garðarsdóttir \& Dittmar, 2012; Sabri, Cook, \& Gudmunson, 2012; Gutter \& Copur, 2011). Even, the most often cited InCharge Financial Distress/Financial Well Being (IFDFW) scale by Prawitz et al. (2006) offers no operational definition of financial wellbeing.

Different research used different indicators for objective and subjective dimensions of financial wellbeing. Some objective financial wellbeing indicators were household's abilities to manage cash flow (Aggarwal, 2011), students' level of debt (Shim, Xiao, Barber, \& Lyons, 2009), financial information and financial ratios (Garrett \& James III, 2013). Subjective financial wellbeing indicators include individuals' satisfaction towards their financial situations and worries about debt (Coşkuner, 2016; Vosloo, Fouché, \& Barnard, 2014).

Despite the various definitions and scales of financial wellbeing, the concepts of financial wellbeing can be classified into three frameworks (Brüggen et al., 2017). The first framework believes that financial wellbeing contains objective and subjective characteristics; the second and third frameworks either consider financial wellbeing as objective or subjective characteristics. The above definition reflects the subjective view of financial wellbeing. The adoption of the subjective model within this study is preferred due to two reasons. Firstly, this model is more comprehensive as it includes non-financial matters. Secondly, this model is more suitable to understand a complicated and personal concept, like financial wellbeing (Brüggen et al., 2017).

\section{Online Shopping Addiction}

Online shopping addiction is an individual's behavior motivated by an uncontrollable shopping urge, and reflected by spending much time and energy into shopping that it harms other significant life aspects (Andreassen et al., 2015). To understand the concept of online shopping addiction, it is compulsory to review previous studies because the concept definition has evolved over time. Prior studies define unregulated shopping behavior as addictive (Krych, 1989), compulsive (Faber \& O'Guinn, 1992), and impulsive (Rook \& Fisher, 1995).

Addictions to shop are represented by individuals' inability to control their shopping urge (Krych, 1989). Faber and O'Guinn (1992) cited in Spinella et al. (2014) explain compulsive buying as "chronic, repetitive purchasing that becomes a primary response to negative events or feelings". Impulsive buying refers to the tendency to shop "spontaneously, unreflectively, immediately, and kinetically" (Rook \& Fisher, 1995). Given this background, there has been long debate about the nature of excessive buying in the scientific environment: is it compulsive, impulsive, or addictive? (Andreassen et al., 2015; Aboujaoude, 2014).

Recent studies contend that it is more appropriate to understand excessive buying as addictive because it is caused by an uncontrolled urge and some of its symptoms are similar with addiction symptoms, namely longing, withdrawal, and loss of control (Lam \& Lam, 2017; Manchiraju, Sadachar, \& Ridgway, 2016; Andreassen et al., 2015; Workman \& Paper, 2010). An attempt has been made to define and measure online shopping addiction because previous scales are considered to be out-of-date, developed under compulsive approach, and in the offline-shopping context (Andreassen et al., 2015). Other scholars embrace this approach, such as Albrecht, Kirschner, and Grüsser (2007), Hartston (2012), and Davenport, Houston, and Griffiths (2012).

\section{Relationship between the Concept and the Hypothesis of the Study}

Early research on the topic of financial knowledge has shown that students with a high level of financial knowledge produced better investment, insurance choice, and spending tendencies (Chen \& Volpe, 1998). When individuals have adequate financial knowledge, they can assess their financial situation appropriately. Moreover, they can understand the financial impacts of their activities. Indeed, they have sufficient knowledge of financial products, including the risks and benefits. Thus, they are more likely to use money wisely, have effective money management, and make the right financial decisions (Taft, Hosein, Mehrizi, \& Roshan, 2013; Robb, 2011; Shim, 
Barber, Card, Xiao, \& Serido, 2010). Even though results of some studies showed support that more knowledgeable individuals tend to engage in positive financial behavior (Robb, 2011; Shim et al., 2010), some scholars found contradictory results. In fact, they found that higher financial knowledge was related to higher credit card loan (Norvilitis \& MacLean, 2010; Robb \& Sharpe, 2009; Borden, Lee, Serido, \& Collins, 2008) since more financial knowledge decreases the anxiety of utilizing credit cards.

Lam and Lam's (2017) study also revealed that there was a correlation between financial literacy and problematic internet shopping (PIS) as based on Interaction of Person-Affect-Cognition-Executive model (I-PACE) financial literacy including financial knowledge can be considered as a personal characteristic that influences PIS. Individuals with higher financial knowledge are less prone to PIS because they understand the risks of PIS for their financial situation. Besides financial knowledge, studies showed that financial wellbeing is linked with financial behaviors, such as paying credit card bills (Garðarsdóttir \& Dittmar, 2012), financial management behaviors (Shim et al., 2009), and problematic financial behavior (Worthy, Jonkman, \& Blinn-Pike, 2010). Another study by Gutter and Copur (2011) demonstrated that financial wellbeing was linked with saving and compulsive buying. It is suggested that financial wellbeing reflects an individual's quality of life; hence, an individual with low financial wellbeing has higher potentiality to feel fear and stress in facing financial obstacles and pressures (Gutter \& Copur, 2011). These situations can lead to uncontrolled actions aimed at distraction and to give immediate pleasure, like PIS.

$H_{l}$ : Young Indonesians' online shopping addiction level will differ by their financial knowledge and financial wellbeing levels.

$H_{2}$ : There is a correlation between financial knowledge and financial wellbeing with online shopping addiction.

$H_{3}$ : There are influences from financial knowledge and financial wellbeing to online shopping addiction.

\section{Research Method}

\section{Data and Sample}

This study utilized purposive sampling since there existed two sample criteria. Firstly, respondents had to be between 18-22 years old, which is the age span when early shopping addiction occurs (Roberts \& Roberts, 2012; Li, Jiang, An, Shen, \& Jin, 2009; Phau \& Woo, 2008). Secondly, respondents had shopped online at least one time within the span of one month. Data was collected between December 2017 and January 2018 using an online survey. The total number of respondents was 230. Demographic information of the respondents is listed on Table 1.

Table 1

Demographic Information of the Respondents

\begin{tabular}{lc}
\hline Demographics & \\
\hline Gender & \\
Male & $45.65 \%$ \\
Female & $54.35 \%$ \\
Educational Background & \\
Economics & $59.57 \%$ \\
Non-economics & $40.43 \%$ \\
Employment Status & \\
Student & $90.43 \%$ \\
Employed & $9.13 \%$ \\
Non-employed & $0.43 \%$ \\
Have Personal Income? & \\
Yes & $29.57 \%$ \\
Not yet & $70.43 \%$ \\
\hline Internet Shopping Behaviour & \\
Spending on shopping (per month) & \\
Below 3 million IDR & $95.65 \%$ \\
3 million IDR and above & $4.35 \%$ \\
Shopping Frequency (per month) & \\
Once & $58.70 \%$ \\
2-3 times & $30.43 \%$ \\
$3-5$ times & $3.91 \%$ \\
More than 5 times & $6.96 \%$ \\
Shopping Items & \\
Fashion & $38.26 \%$ \\
Food and Beverage & $24.35 \%$ \\
Electronics & $15.65 \%$ \\
Health care products & $8.70 \%$ \\
Game & $5.22 \%$ \\
Others & $7.83 \%$ \\
\hline
\end{tabular}

\section{Measurement of Variables \\ Online shopping addiction}

The Bergen Shopping Addiction Scale (BSAS) from Andreassen et al. (2015) was used to assess online shopping addiction. The BSAS consists of seven items based on seven addiction criteria, namely salience, mood modification, conflict, tolerance, relapse, withdrawal, and problems (Andreassen et al., 2015). Salience is individuals' preoccupation with the intended activity (i.e. online shopping). Mood modification refers to online shopping as a coping strategy. Tolerance implies that an increase in the amount of online shopping needs to be achieved to experience mood changes as time passes. Withdrawal contains unpleasant feelings or negative physical influences when someone stops or greatly reduces online shopping. Conflict refers to disputes arising in other 
spheres of life (e.g. interpersonal conflict) due to excessive online shopping. Relapse is the tendency to continue the previous pattern of online shopping behavior. Problem refers to the symptoms that arise from online shopping addiction (e.g., welfare).

Some items in the scale are "I think about shopping/buying things all the time", "I have decided to shop/buy less, but have not been able to do so", and "I feel bad if for some reason I am prevented from shopping/buying things." The instrument used fivepoint Likert-type responses, ranging from (1) strongly agree to (5) strongly disagree. The total score of the scale shows the level of online shopping addiction.

\section{Financial Knowledge}

Financial knowledge was operationalized as individuals' understanding of basic financial concepts. To measure financial knowledge, four items were adopted from Australian Unity's scale of financial literacy (2014). Those four items test individuals' knowledge of interest rates, inflation, shares, and retirement savings. Examples of the items are "Buying shares in a single company usually provides a safer return than buying units in a managed share fund" and "Employees cannot make superannuation payments additional to any payments made by their employer." The response choices for the scale were (1) False and (2) True.

\section{Financial Wellbeing}

Financial wellbeing was defined as individuals' overall emotions about their current financial situation. Personal Financial Wellbeing Index from Australian Unity (2014) was adopted to assess financial wellbeing. The index contains 12 items and it is a five-point Likert-type scale ( 1 = strongly disagree, $5=$ strongly agree). The items include "I am comfortable managing my personal debt", "My personal finances are completely out of control", and "I always pay my bills on time."

\section{Result and Discussion}

\section{Data Analysis}

To analyze the data, we used SPSS 24.0. First, assessment of internal scale reliability of all scales was conducted using Cronbach's $\alpha$ coefficient. Second, descriptive analysis was employed on all the research variables. Third, cross tabulation was performed to analyze levels of financial knowledge, financial wellbeing, and online shopping addiction. Fourth, to test hypothesis 2, Pearson correlation was implemented. Lastly, multiple regression analysis was administered to investigate the impact of financial knowledge and financial wellbeing toward online shopping addiction.

\section{Result}

To ensure that all scales were fit, validity and reliability tests were conducted. It was found that all scales were valid because each scale had an $r$-value greater than its $r$-table. The results of Cronbach's $\alpha$ of all the scales were higher than 0.70; and, thus, it confirmed that all scales were reliable. The results of the descriptive statistics for all variables are displayed in Table 2. The average score for online shopping addiction is 14.74 whereas financial knowledge obtains 6.19 and financial wellbeing results in 36.36 .

Table 2

Descriptive Statistics for All Variables

\begin{tabular}{lrrr}
\hline & Freq. & Mean & SD \\
\hline Online Shopping Addiction & & 14.74 & 5.19 \\
$\quad$ Addictive & $6.52 \%$ & & \\
$\quad$ Not Addictive & $93.48 \%$ & & \\
Financial Knowledge & & 6.19 & 1.217 \\
$\quad$ Low & $21.74 \%$ & & \\
$\quad$ Medium & $60.00 \%$ & & \\
$\quad$ High & $18.26 \%$ & & \\
Financial Wellbeing & & 36.36 & 5.782 \\
$\quad$ Low & $27.83 \%$ & & \\
$\quad$ Medium & $44.78 \%$ & & \\
$\quad$ High & $27.39 \%$ & & \\
\hline
\end{tabular}

Possible scores for: Financial Wellbeing (1260), Financial Knowledge (4-8), Online Shopping Addiction (7-35).

In the research, respondents were measured to be addictive when they scored 4 (agree) or 5 (strongly agree) in more than 3 of the 7 items. This norm was used based on Andreassen et al. (2015) suggestion. We categorized financial knowledge into three kinds based on the total number of correct items as recommended by Australian Unity (2014), namely low level for 0-1 correct items, medium level for 2-3 correct items, and high level for all correct items. In terms of financial wellbeing index, we used the percentile distribution of the scores as categorization standard (Australian Unity, 2014). Respondents below $25^{\text {th }}$ percentile were categorized as having a low level of financial wellbeing whilst those within $75^{\text {th }}$ percentile were having a high level of financial wellbeing. The results of cross tabulation between all research variables can be seen in Table 3. More than $90 \%$ of the respondents were not addictive; yet, the ones who were addictive had better levels of financial knowledge and financial wellbeing. 
Table 3

Cross Tabulations Between All Variables

\begin{tabular}{lrc}
\hline & \multicolumn{2}{c}{ Online Shopping Addiction } \\
\cline { 2 - 3 } & Not Addictive & Addictive \\
\hline Financial Knowledge & & \\
Low & $21.74 \%$ & $0 \%$ \\
Medium & $57.39 \%$ & $2.61 \%$ \\
High & $14.35 \%$ & $3.91 \%$ \\
$\quad$ Total & $93.48 \%$ & $6.52 \%$ \\
Financial Wellbeing & & \\
Low & $27.39 \%$ & $0.43 \%$ \\
$\quad$ Medium & $43.04 \%$ & $1.74 \%$ \\
High & $23.04 \%$ & $4.35 \%$ \\
$\quad$ Total & $93.48 \%$ & $6.52 \%$ \\
\hline
\end{tabular}

Table 4

Results of Pearson Correlation and Multiple Regression Analysis

\begin{tabular}{lcc}
\hline & $\begin{array}{c}\text { Financial } \\
\text { Knowledge }\end{array}$ & $\begin{array}{c}\text { Financial } \\
\text { Wellbeing }\end{array}$ \\
\hline Pearson $(r)$ & $0.142^{*}$ & $0.311^{* * *}$ \\
$B$ & 0.334 & 0.264 \\
$S E$ & 0.275 & 0.058 \\
$\beta$ & 0.078 & 0.294 \\
$T$ & 1.213 & 4.565 \\
$p$ & 0.226 & $0.000^{* * * *}$
\end{tabular}

\begin{tabular}{ll} 
Constant & \\
$R^{2}$ & 0.103 \\
Adjusted $R^{2}$ & 0.095 \\
$S E$ & 4.942 \\
\hline
\end{tabular}

Correlation is significant at 0.01 level (2-tailed)

Correlation is significant at 0.05 level (2-tailed)

\section{Discussions}

Upon statistical analysis, the study revealed that less than $7 \%$ of respondents were addictive and around $4 \%$ of them had high levels of financial knowledge and financial wellbeing (Table 3). A possible explanation for this outcome was due to only few respondents had steady employment; and thus, they had income to engage in more online shopping addiction. Also, respondents with high scores of financial knowledge and financial wellbeing had better understanding of financial concepts and were more satisfied with their financial situation; hence, they were comfortable in fulfilling their uncontrollable shopping urge. The findings of this research are in line with Borden et al. (2008), who confirmed that individuals with better financial knowledge were confident when using credit cards.

Generally, individuals with low levels of financial knowledge and financial wellbeing were not addicted to online shopping. As for those with me- dium financial knowledge and financial wellbeing levels, these had little tendency to be addicted to online shopping. Interestingly, there were online shopping addicts who had low levels of financial wellbeing. It is argued that addicted individuals tend to utilize online shopping as their coping strategy to remove negative emotions, such as dissatisfaction towards their financial situations (Davenport et al., 2012). The immediate pleasure after purchasing online decreases their feelings of discontent. Given this explanation, hypothesis 1 is supported, that young Indonesians' levels of online shopping addiction will vary according to their levels of financial knowledge and financial wellbeing.

The outcomes of this study confirmed hypothesis 2 that financial knowledge and financial wellbeing were positively related to online shopping addiction. This demonstrates that the higher the financial knowledge and financial wellbeing scores, the higher the online shopping addiction scores. Similar results were also shown from the results of multiple regression analysis. Financial knowledge positively influences online shopping addiction although it is not significant whereas financial wellbeing has a significant positive effect on online shopping addiction. Hence, hypothesis 3 was also supported. These results are contradictory with Shim et al. (2010), Gutter and Copur (2011), and Robb (2011); yet, similar with Robb and Sharpe (2009) and Norvilitis and MacLean (2010). Although financial knowledge did not significantly influence online shopping addiction, individuals used their high knowledge of financial concepts to support them in finding best deals when shopping online. Additionally, financial wellbeing was a better predictor for online shopping addiction since individuals who have positive feelings about their current financial issues tend to be more secure in increasing their spending behavior.

\section{Conclusions and Implications}

\section{Conclusions}

This study attempted to fill the gaps in the existing research by investigating the roles of financial knowledge and financial wellbeing on online shopping addiction. In conclusion, online shopping addiction levels would vary according to financial knowledge and financial wellbeing levels. Also, financial knowledge and financial wellbeing were positively related to online shopping addiction. Moreover, financial wellbeing significantly influenced online shopping addiction among young Indonesians. 


\section{Implications}

The outcomes of this research offer important insights that individuals with high scores of financial knowledge and financial wellbeing are more likely to be addicted to shop online. Previous scholars have had different results, as they state that financially knowledgeable individuals use their understanding to manage money wisely and invest more often (Robb, 2011; Shim et al., 2010). Yet, as proven by this study, those individuals feel more positive about their financial knowledge and financial conditions; thus, they tend to buy more goods through online shops and they may get addicted to online shopping. However, a point worth noting is that studies with more heterogeneous respondents are needed to ensure consistent results.

This study confirms the association of financial knowledge and financial wellbeing with online shopping addiction. Although more than $90 \%$ of the respondents were not addictive, there is a risk of a higher number of Indonesian online shopping addicts in the near future. Online shopping addiction may be just as damaging as gambling. Thus, for individuals who are prone to online shopping addiction, some activities that can help them including deleting all digitallystored credit cards numbers, informing significant others about their addiction and asking for their help, exercising or developing constructive hobbies, and more importantly pursuing professional treatment. Also, it is essential for the Indonesian government to provide assistance such as proven psychological therapy and intervention to manage online shopping addiction, namely Cognitive Behavioral Therapy for Internet Addiction (CBT-IA) (Young, 2013) and financial counseling. In addition, increasing individuals' financial knowledge, skills, and attitudes through education and training programs organized by the government with the supervision of a financial expert is necessary to prevent problematic financial behavior such as online shopping addiction.

\section{Limitations}

This study is limited by the characteristics of the respondents who were majority college students who did not have personal incomes. Less heterogeneous respondents may cause similarities in online shopping behavior. Future research is suggested to use respondents from different backgrounds in terms of economic condition, race, and age. Indeed, to make a generalization, studies with a more comprehensive sampling method are required. Another weakness in this study is the use of self-report data that may induce a possibility of biases and inaccuracies. However, the utilization of reliable and validated scales with clear definitions and indicators reduced some of the above factors. Further research may use objective measures to test the consistency of the outcomes of this study, such as income levels or debt ratios.

\section{References}

Aboujaoude, E. (2014). Compulsive buying disorder: A review and update. Current Pharmaceutical Design, 20(25), 4021-4025.

Aggarwal, S. (2011). Developing an index for measuring financial well-being in geography. Retrieved from https://www.dvara.com/blog /2011/ 02/14/developing-an-index-for-mea suring-financial-well-being-in-a-geograp hy/.

Albrecht, U., Kirschner, N. E., \& Grüsser, S. M. (2007). Diagnostic instruments for behavioral addictions: An overview. Psychosoc. Med., 4, 1-11.

Andreassen, C. S., Griffiths, M. D., Pallesen, S., Bilder, R. M., Torsheim, T., \& Aboujaoude, E. (2015). The Bergen shopping addiction scale: Reliability and validity of a brief screening test. Frontiers in Psychology, 6, 1-11.

Australian Unity (2014). Financial wellbeing questionnaire-Design and validation. Victoria, Melbourne: Australian Unity.

Barlian, J. K. (2017). Business research. SWA. Retrieved from https://swa.co.id/swa/trends/ business-resear ch/google-tren-belanja-e-commerce-tidak-terpusat-di-jakarta.

Bighiu, G., Manolică, A., \& Roman, C. T. (2015). Compulsive buying behavior on the internet. Procedia Economics and Finance, 20(15), 72-79.

Boediono, L. (2018). Indonesia continues to build on solid economic growth. Retrieved from http:// www.worldbank.org/en/news/press-release/ 2018/03/27/indonesia-continues-to-build-onsolid-economic-growth.

Borden, L. M., Lee, S., Serido, J., \& Collins, D. (2008). Changing college students' financial knowledge, attitudes, and behavior through seminar participation. Journal of Family and Economic Issues, 29(1), 23-40.

Bowen, C. F. (2002). Financial knowledge of teens and their parents. Journal of Financial Counseling and Planning, 13(2), 93-102.

Brand, M., Young, K. S., Laier, C., Wölfling, K., \& Potenza, M. N. (2016). Integrating psychological and neurobiological considerations regarding the development and maintenance of specific Internet-use disorders: An Interaction of Person- 
Affect-Cognition -Execution (I-PACE) model. Neuroscience and Biobehavioral Reviews, 71, 252-266.

Brüggen, E. C., Hogreve, J., Holmlund, M., Kabadayi, S., \& Löfgren, M. (2017). Financial wellbeing: A conceptualization and research agenda. Journal of Business Research, 79, 228-237.

Chen, H., \& Volpe, R. P. (1998). An analysis of personal financial literacy among college students. Financial Services Review, 7(2), 107-128.

Clark, M., \& Calleja, K. (2008). Shopping addiction: A preliminary investigation among Maltese university students. Addiction Research and Theory, 16, 633-649.

Coşkuner, S. (2016). Understanding factors affecting financial satisfaction: The influence of financial behavior, financial knowledge and demographics. Imperial Journal of Interdisciplinary Research, 2(5), 377-385.

Davenport, K., Houston, J. E., \& Griffiths, M. D. (2012). Excessive eating and compulsive buying behaviours in women: An empirical pilot study examining reward sensitivity, anxiety, impulsivity, self-esteem and social desirability. International Journal of Mental Health and Addiction, 10(4), 474-489.

Dolan, P., Peasgood, T., \& White, M. (2008). Do we really know what makes us happy? A review of the economic literature on the factors associated with subjective wellbeing. Journal of Economic Psychology, 29(1), 94-122.

Duroy, D., Gorse, P., \& Lejoyeux, M. (2014). Characteristics of online compulsive buying in Parisian students. Addictive Behaviors, 39(12), 1827-1830.

Faber, R. J., \& O'Guinn, T. C. (1992). A clinical screener for compulsive buying. Journal of Consumer Research, 19(3), 219-225.

FocusEconomics. (2017). Consumption in Indonesia. Retrieved from https://www.focus-eco nomics.com/country-indicator/indonesia/co nsumption.

Garðarsdóttir, R. B., \& Dittmar, H. (2012). The relationship of materialism to debt and financial well-being: The case of Iceland's perceived prosperity. Journal of Economic Psychology, 33(3), 471-481.

Garrett, S., \& James III, R. N. (2013). Financial ratios and perceived household financial satisfaction. Journal of Financial Therapy, 4(1), 39-62.

Gutter, M., \& Copur, Z. (2011). Financial behaviors and financial well-being of college students: Evidence from a national survey. Journal of Family and Economic Issues, 32(4), 699-714.
Hartston, H. (2012). The case for compulsive shopping as an addiction. Journal of Psychoactive Drugs, 44(1), 64-67.

Huston, S. J. (2010). Measuring financial literacy. Journal of Consumer Affairs, 44(2), 296-316.

Jati, W. (2015). Less cash society: Menakar mode konsumerisme baru kelas menengah Indonesia. Jurnal Sosioteknologi, 14, 102-112.

Kimiyaghalam, F., \& Safari, M. (2015). Review papers on definition of financial literacy and its measurement. SEGi Review, 8, 81-94.

Krych, R. (1989). Abnormal consumer behavior: A model of addictive behaviors. Advances in Consumer Research, 16, 745-748.

Lam, L. T., \& Lam, M. K. (2017). The association between financial literacy and problematic internet shopping in a multinational sample. Addictive Behaviors Reports, 6, 123-127.

Li, D., Jiang, Y., An, S., Shen, Z., \& Jin, W. (2009). The influence of money attitudes on young Chinese consumers' compulsive buying. Young Consumers, 10(2), 98-109.

Lo, H., \& Harvey, N. (2012). Effects of shopping addiction on consumer decision-making: Webbased studies in real time. Journal of Behavioral Addictions, 1(4), 162-170.

Manchiraju, S., Sadachar, A., \& Ridgway, J. L. (2016). The Compulsive Online Shopping Scale (COSS): Development and validation using panel data. International Journal of Mental Health and Addiction, 15(1), 209-223.

Norvilitis, J. M., \& MacLean, M. G. (2010). The role of parents in college students' financial behaviors and attitudes. Journal of Economic Psychology, 31(1), 55-63.

Oberman, R., Dobbs, R., Budiman, A., Thompson, F., \& Rossé, M. (2012). The archipelago economy: Unleashing Indonesia's potential. Retrieved from McKinsey Global Institute website: https://www.mckinsey.com.

Organization for Economic Co-operation and Development. (2012). OECD/INFE high-level principles on national strategies for financial education. Paris, France: OECD.

Oktara, D. (2017). Gubernur bi: Transaksi belanja online capai Rp 75 Triliun. Tempo. Retrieved from https://bisnis.tempo.co/read/8986 38/gubernur-bi-transaksi-belanja-online-c apai-rp-75triliun.

Phau, I., \& Woo, C. (2008). Understanding compulsive buying tendencies among young Australians. Marketing Intelligence \& Planning, 26(5), 441-458. 
Prawitz, A. D., Garman, E. T., Sorhaindo, B., O'Neill, B., Kim, J., \& Drentea, P. (2006). InCharge financial distress/financial well-being scale: Development, administration, and score interpretation. Journal of Financial Counseling and Planning, 17(1), 34-50.

Robb, C. A. (2011). Financial knowledge and credit card behavior of college students. Journal of Family and Economic Issues, 32(4), 690-698.

Robb, C., \& Sharpe, D. (2009). Effect of personal financial knowledge on college students' credit card behavior. Journal of Financial Counseling and Planning, 20(1), 25-43.

Roberts, J. A., \& Roberts, C. (2012). Stress, gender and compulsive buying among early adolescents. Young Consumers, 13(2), 113-123.

Rook, D. W., \& Fisher, R. J. (1995). Normative influences on impulsive buying behavior. Journal of Consumer Research, 22(3), 305-313.

Rose, S., \& Dhandayudham, A. (2014). Towards an understanding of Internet-based problem shopping behaviour: The concept of online shopping addiction and its proposed predictors. Journal of Behavioral Addictions, 3(2), 83-89.

Sabri, F. M., Cook, C. C., \& Gudmunson, C. G. (2012). Financial well-being of Malaysian college students. Asian Education and Development Studies, 1(2), 153-170.

Sari, E. V. (2014). Berita keuangan. Retrieved from https://www.cnnindonesia.com/ekonomi/20141 220232435-78-19533/ojk-pendap atan-meningkat-masyarakat-cenderung-ko nsumtif.

Shim, S., Barber, B. L., Card, N. A., Xiao, J. J., \& Serido, J. (2010). Financial socialization of firstyear college students: The roles of parents, work, and education. Journal of Youth and Adolescence, 39(12), 1457-1470.
Shim, S., Xiao, J. J., Barber, B. L., \& Lyons, A. C. (2009). Pathways to life success: A conceptual model of financial well-being for young adults. Journal of Applied Developmental Psychology, 30(6), 708-723.

Spinella, M., Lester, D., \& Yang, B. (2014). Compulsive buying tendencies and personal finances. Psychological Reports, 115(3), 670-674.

Strömbäck, C., Lind, T., Skagerlund, K., Västfjäll, D., \& Tinghög, G. (2017). Does self-control predict financial behavior and financial well -being? Journal of Behavioral and Experimental Finance, 14, 30-38.

Taft, M. K., Hosein Z. Z., Mehrizi S. M. T., \& Roshan, A. (2013). The relation between financial literacy, financial wellbeing and financial concerns. International Journal of Business and Management, 8(11), 63-75.

United States Government Accountability Office (2012). Financial literacy: The federal government's role in empowering Americans to make sound financial choices. Washington, DC: US Government Accountability Office.

Vosloo, W., Fouché, J., \& Barnard, J. (2014). The relationship between financial efficacy, satisfaction with remuneration and personal financial wellbeing. International Business and Economics Research Journal, 13(6), 1455-1470.

Workman, L., \& Paper, D. (2010). Compulsive buying: a theoretical framework. The Journal of Business Inquiry, 9(1), 89-126.

Worthy, S. L., Jonkman, J., \& Blinn-Pike, L. (2010). Sensation-seeking, risk-taking, and problematic financial behaviors of college students. Journal of Family and Economic Issues, 31(2), 161-170.

Young, K. S. (2013). Treatment outcomes using CBT-IA with Internet-addicted patients. Journal of Behavioural Addictions, 2(4), 209-215. 